\title{
HRM PRACTICES AND ITS IMPACT ON EMPLOYEE PERFORMANCE: A STUDY OF THE CEMENT INDUSTRY IN INDONESIA
}

\author{
Ridwan $^{1)}$, H. Mursalim Umar Gani' ${ }^{2}$, H. Achmad Gani ${ }^{3)}$, H. Sunusi Hamid ${ }^{4)}$ \\ ${ }^{1)} \mathrm{PhD}$ Candidate (Muslim University of Indonesia) Makassar, Indonesia \\ ${ }^{2,3,4)}$ Lecturer in Management Science, Muslim University of Indonesia, Indonesia
}

\begin{abstract}
This research aims to examine and analyze the effect of human resource management practices (i.e. leadership styles, employee commitment, work motivation, and work climate) on employee job satisfaction and employee performance. This study used primary data obtained through a survey to 221 employees as a sample. The result of Structural Equation Modelling (SEM) analysis shows that empirically the leadership style, employee commitment, work motivation, and work climate have positive and significant impact on job satisfaction. Leadership style, employee commitment, work motivation, and work climate, either directly or indirectly have a positive and significant effect on employee performance through job satisfaction as variable intervening. Job satisfaction has a direct positive and significant effect on employee performance. The direct effect of leadership styles, employee commitment, motivation and work climate on employee performance is positive, which means that when the exogenous variables improved the job satisfaction and employee performance will increase. The indirect effect of exogenous variable on employee performance through job satisfaction is positive. The total effect which is the sum of the direct and indirect effects through job satisfaction obtained positive value, which means there is effect of direct effect and indirect effect of exogenous variable on employee performance through job satisfaction.
\end{abstract}

Keywords: HRM Practice, job satisfaction, employee performance

\section{INTRODUCTION}

Every company has a specific purpose according to their respective field of business, but the main goal to be achieved is profit in addition to other goals, such as the continuity of corporate life and participation in improving the welfare of the community. To that end, a company that wants to maintain its existence better, then the most fundamental is the ability of the leadership of the company to manage all existing potentials effectively and efficiently and the utilization of 


\section{International Journal of Arts and Humanities}

ISSN: 2581-3102

Volume:02, Issue:05 "May 2018"

existing labor (human resource management practices) will affect the improvement of employee performance including employees at PT Semen Tonasa (Pangkajene Islands Regency).

The Company strives to improve itself through continuous evaluation and development. With the support of strong human and capital resources, synergize with the strength of a reliable managerial strategy, where improvement is expected to create sustainable growth of corporate profitability through improved employee performance. According to Mangkunegara (2006), employee performance factors consist of: individual factors and environmental factors of the organization. Individual factors include: competence, trust, experience, commitment, reward and so on. While the organizational factors include: leadership style, motivation, compensation, work climate, authority, responsibility, control system. Impact of human resource management practices (HRM Practices) on employee performance has been a widely researched area for years. Several scholars have noted that managing people is more difficult than managing technology or capital (Barney, 1991). However those firms that have learned how to manage their human resources are cumbersome and take much longer time (Wright et al., 2003).

The role of leadership, employee commitment is also one of the predictors for job satisfaction and employee performance. Employees who have high work commitment are needed to achieve maximum individual performance. Greenberg \& Baron (2003) suggests commitment to reflect the degree of individual identification and involvement in his work and to his unwillingness to leave work. Commitment is a part related to a person's performance in relation to his work. In a commitment also has an element or components that are interconnected. When all components are fulfilled the greater the commitment of a person to his work. According to Robbins \& Judge (2007), commitment is the power of a person's identification of an organization and involvement in the organization and its values and there is no willingness to provide power on behalf of the organization in formulating a strategic plan.

The commitment of employees at PT Semen Tonasa (Pangkajene Islands Regency) is still relatively low. It can be seen there are still employees who cannot complete their duties properly according to work standards that have been determined. The emergence of absenteeism and the onset of anxiety in work reflect low employee commitment. This phenomenon also happens to employees of PT Semen Tonasa, where employees in the work not seriously and have no responsibility for his progress. Therefore, employee commitment needs to be studied because it is believed to have an impact on job satisfaction and employee performance at PT Semen Tonasa. Increased job satisfaction and employee performance, not only enough to understand employee leadership and commitment, but also provide motivation to work in various forms and ways so as to encourage and improve employee morale, which in turn will create job satisfaction and employee performance. Improve wage systems and provide more humane incentives, able to 
International Journal of Arts and Humanities

ISSN: 2581-3102

Volume:02, Issue:05 "May 2018"

encourage morale while improving skills and skills in achieving good work. Work motivation can lead to behaviors that reflect high performance in the organization. Employees, who have high work motivation, tend to try to improve the ability to complete the work (Richard L. Daft, 2006).

Work climate is often mentioned with the climate of the organization, because work is one unity of the organization. Work climate has a great influence on job satisfaction and employee performance. The term working climate was first used by Kurt Lewin in the 1930s, which used the term psychological climate, then the term working climate was used by Tagiuri et al. (1968) that the working climate is everything that exists in the work environment that is lived as a subjective influence of the formal system, the information style of the manager, and other important environmental factors on the attitudes, beliefs, values, and motivations of the people working in the organization certain. Thus, the work climate is created as a result of a combination of several things, past experiences, the effects of the constraints created in the organizational system, the special needs, the expectations, the superior leadership and the communication and informal relationships between superiors and members of the organization.

The work climate at PT Semen Tonasa is still less supportive, such as less pleasant work atmosphere, lack of support from colleagues, and employee work load. In addition, there are still many elements of work climate of production employees that have the potential to bring accidents and inconvenience, among others: noise, air pollution, engine damage, work accidents and others. Work climate is an importance because the work climate is very influential with job satisfaction and employee performance. Job satisfaction according to Handoko (2002) is a pleasant or unpleasant work environment where employees look at their work. Job satisfaction occurs when the individual needs are met and associated with the degree of joy and dislike associated with employees is a common attitude owned by employees who are closely related to the rewards that are believed to be received after a sacrifice.

\section{LITERATURE REVIEW}

Leadership styles

Leadership is implemented when one mobilizes institutional, political, psychological, and other resources to awaken, engage and fulfil the motivation of its followers. Leadership is the individual's ability to influence, motivate, and enable others to contribute to the effectiveness and success of the organization (Burns, 1978; Yukl \& Lepsinger, 2005). Leadership roles include motivating subordinates and creating favourable conditions in carrying out the work (Bass, 1990). The effectiveness of the leader is influenced by the characteristics of his subordinates and 
International Journal of Arts and Humanities

ISSN: 2581-3102

Volume:02, Issue:05 "May 2018"

is related to the communication process that occurs between the leader and the subordinate. Leadership plays a significant role in the success and failure of an organization.

Robins (2006) identifies four types of leadership styles: (1) Charismatic leadership style, (2) Transactional leadership style, (3) Transformational leadership style, (4) Visionary leadership style. Effective leadership styles are essential for shaping and improving the performance of individuals, groups and organizations, so there are many attempts to find the cause for such effective leadership (Gibson et al., 1994). The results of previous studies show that transformational leadership styles measured by idealized influencers attributes, idealized influencers behaviours, inspirational motivation, intellectual stimulation, and individualized consideration have a positive and significant effect on job satisfaction (Boamah et al., 2017). Similar results also found other researchers that the transformational leadership style and transactional leadership style have a positive and significant effect on job satisfaction (Adler \& Reid, 2008; Golabdost \& Rezaei, 2017; Hijazi et al., 2017; Lapeña et al., 2018). The evidence receives a rebuttal from other researchers, that leadership styles do not have any significant influence on job satisfaction (Yudiawan et al., 2017; Muterera et al., 2018). In other causality found evidence that leadership style has a significant effect on employee performance (Thamrin, 2012). The evidence gains a rebuttal from other researchers, that leadership styles do not have any significant influence on the construction job performance (Adler \& Reid, 2008; Yudiawan et al., 2017; Muterera et al., 2018).

Employee Commitment

According by Steers \& Porter (2001) commitment as a sense of identification (trust in organizational), involvement (willingness to do the best possible for the benefit of the organization) and loyalty (the desire to remain a member of the organization concerned) organization. Commitment is a condition in which employees are very interested in the goals, values, and objectives of the organization. Commitment to the organization means more than just formal membership, as it includes an attitude of liking to the organization and a willingness to seek high levels of effort for the benefit of the organization for the achievement of the goal. Commitment is a relative strength of the individual in identifying organization. It can be characterized by three things, namely: (1) Acceptance of organizational values and objectives; (2) Readiness and willingness to strive earnestly on behalf of the organization; and (3) The desire to maintain membership within the organization (becoming part of the organization) (Robbins, 2006).

The view of other scholars (Lee et al., 2001) distinguishes commitments into three components as follows: (1) the affective commitment the employee's emotional attitude is bound to its involvement in the organization. Workers with strong affective commitment will always do the 
International Journal of Arts and Humanities

ISSN: 2581-3102

Volume:02, Issue:05 "May 2018"

work they are responsible for, (2). The continuance commitment is a commitment based on the cost to be borne by the employee if he leaves the organization. (3) Normative commitment, namely the responsibility of employees to keep working on the organization because it is considered as a thing that should be. The results of previous studies show that employees' commitment (affective, continuance and career commitment) has a positive and significant impact on employee performance (Carmeli \& Freund, 2003; Thamrin, 2012; Toban \& Sjahruddin, 2016). Other facts show that organizational commitment was confirmed to have a significant impact on job performance (Carmeli \& Freund, 2003; Thamrin, 2012; Sjahruddin \& Sudiro, 2013; Fu \& Deshpande, 2014).

Work Motivation

The variety of terms used to describe the motivation, among others: the need, urge, wish, and drive. Thus, the motivation of the basic word motive is the driving force or driving force that drives the human to act or a force within the human that causes man to act. Koontz (1972) says that motive to the drive effort to satisfy a wants or good (motivation refers to the drive and effort to satisfy a need or a goal). Another scholarly view explains that motivation is a force that encourages an employee to generate and direct behaviour. Thus, motivation is a series of encouragement activities, not only to others but also to oneself. So that through this impulse is expected to be able to act toward the desired destination (Gibson et al., 1994).

Motivation can be generated by internal or external factors depending on the origin of the activity started. Internal motivation comes from one's personal self, while external motivation is built on internal motivation and existence within an organization that is highly dependent on the assumptions and techniques used by the leaders of the organization or managers in motivating their subordinates (Moekijat, 2002). The results of previous studies show that work motivation is not significant to job satisfaction (Pang \& Lu, 2018). The study obtained a rebuttal from other researchers that work motivation has a significant effect on job satisfaction (Hartawan et al., 2014; Ayundasari et al., 2017; Wahab et al., 2018). In other causality tests proving that work motivation significantly affects employee performance (Wright et al., 2003; Ayundasari et al., 2017; Prabowo et al., 2018; Pang \& Lu, 2018)

Work climate

According by Wirawan (2007) climate work is the perception of organizational members (individually and in groups) and those who are constantly in touch with organizations (e.g. suppliers, consumers, consultants, and contractors) about what is or is happening within the organization's internal environment on a regular basis, affecting the attitudes and behaviors of the organization and the performance of organizational members which then determines the 
International Journal of Arts and Humanities

ISSN: 2581-3102

Volume:02, Issue:05 "May 2018"

performance of the organization. Thus, the working climate is the individual's expectations and perspective on the organization. Duncan (1972) characterizes the organizational climate as a whole of the physical and social factors within an organization. Organizational climate can have a profound effect on employee performance. A working climate that focuses on its employees can improve performance. Conversely, inadequate work environment will decrease employee performance.

Climatic conditions are said to be good or appropriate if humans can carry out activities optimally, healthy, safe and comfortable. Work climate suitability can be seen as a result for a long time. Furthermore, a poor working climate may demand more labour and time and do not support the efficient design of work systems (Davis, 2001). Empirical evidence suggests that the work climate has a positive and significant impact on job satisfaction (Barney, 1991; Hartawan et al., 2014; Susanti, 2016; Alim, 2016). Work climate proven to improve individual performance (Normandah \& Fathoni, 2015; Alim, 2016; Hastari et al., 2017; Nugroho et al., 2017).

\section{Job Satisfaction}

Robbins \& Judge (2007) defines job satisfaction as a general attitude of the individual to his work. Furthermore, employee job satisfaction according to Luthans (2000) is defined as a positive or pleasant emotional statement resulting from the assessment of a job or work experience. Therefore, employee satisfaction is the result of employee perceptions of how a job is able to provide the things that are considered important. Handoko (2002) suggests that job satisfaction is a pleasant or unpleasant emotional state in which employees perceive their work. Job satisfaction reflects a feeling of joy to his work; this is often evident in the employee's positive attitude to work and everything that is encountered in his work environment.

The empirical facts show that job satisfaction has a significant influence on the construction of job performance (Barney, 1991, Thamrin, 2012, Alim 2016; Yudiawan et al., 2017; Ayundasari et al., 2017; Muterera et al., 2018; Pang \& Lu, 2018; Prabowo et al., 2018). The results obtained a rebuttal from other researchers, that job satisfaction had no significant impact on job performance (Fu \& Deshpande, 2014; Handayani, 2016).

Employee performance

Mahsun (2006) suggests that performance is the work achieved by an employee through an execution of work or tasks assigned to him in accordance with the time specified, qualified, and accurate on the target by always following the established method. Performance is a real behaviour that is displayed every person as a work performance generated by employees in accordance with its role in the company. Therefore, employee performance is very important in 
International Journal of Arts and Humanities

ISSN: 2581-3102

Volume:02, Issue:05 "May 2018"

the company's efforts to achieve its goals (Rivai, 2008: 309). There are two factors that can be used in measuring employee performance that is Identify dimensions of performance and Performance standard setting. According to Simamora (2004), performance (performance) is influenced by three factors, namely: (1) individual factors consisting of: ability and expertise, background, and demography; (2) psychological factors consisting of: perception, attitude, personality, learning, and motivation; and (3) organizational factors consisting of: resources, leadership, rewards, structure, and job design.

Earlier researchers proved that job satisfaction is not the mediating variable between leadership styles and construction job performance (Yudiawan et al., 2017). Evidence is denied by other researchers that the indirect effect of transformational leadership behaviour on organizational performance, as mediated through job satisfaction, was positive and significant (Muterera et al., 2018). In other causality it is found that there is a meaningful role that the job satisfaction has a mediating role in the relationship between joint work commitment and job performance (Carmeli $\&$ Freund, 2003). The findings are similar to those results, which job satisfaction significantly acts as mediation in analyzing the effect of work motivation on employee performance (Ayundasari et al., 2017; Prabowo et al., 2018). The final causality of research conducted by Alim (2016) proves that there is a significant influence between the work climates on employee performance in mediation job satisfaction.

\section{METHODS}

This research is a quantitative study conducted by using exploratory research to determine the clarity of the influence of each variable that is analyzed. Questionnaires were distributed to 221 employees of PT. Semen Tonasa used as sample. Data analysis was done by utilizing structural equation modeling (SEM) with AMOS assistance 21. 
International Journal of Arts and Humanities

ISSN: 2581-3102

Volume:02, Issue:05 "May 2018"

\section{RESULTS}

Table 1: Characteristics of the sample

\begin{tabular}{lcc}
\hline Characteristics & Frequency & Percent $(\%)$ \\
\hline Gender & & \\
$\quad$ Male & 121 & 54,75 \\
$\quad$ Female & 100 & 45,25 \\
Ages & & \\
$\quad \leq 33$ Years & 12 & 5,43 \\
$34-39$ Years & 90 & 40,72 \\
$40-45$ Years & 53 & 23,98 \\
$\geq 46$ Years & 66 & 29,86
\end{tabular}

Job tenure

$\leq 11$ Years

12- 17 Years

$\geq 18$ Years

Educational level

High School

Associate's degree

Bachelor degree

Master degree

Doctoral degree
28

140

53

81

68

65

6

1
12,67

63,35

23,98

36,65

30,77

29,41

2,71

0,45

The composition of respondents by sex is mostly male gender is 121 people (54.75\%). Based on age dominated by 34-39 years as many as 90 people $(40,72 \%)$. Finally for the level of education of respondents who occupy the most proportion are high school as many as 81 people (36.65\%). 
International Journal of Arts and Humanities

ISSN: 2581-3102

Volume:02, Issue:05 "May 2018"

Descriptive variables

Table 2: Leadership styles

\begin{tabular}{lcccc}
\hline \multicolumn{1}{c}{ Measurements } & Mean & Critical ratio & LDF $(\lambda)$ & P-value \\
\hline knowledge sharing & 4,01 & FIX & 0,47 & 0,000 \\
fair treatment & 3,87 & 6,715 & 0,52 & 0,000 \\
Helping subordinates & 4,11 & 7,789 & 0,60 & 0,000 \\
Personal attention & 4,00 & 17,541 & 0,46 & 0,000 \\
Detailed procedures & 3,85 & 5,855 & 0,51 & 0,000 \\
Obey the rules & 4,05 & 6,675 & 0,65 & 0,000 \\
Priority scale of interest & 4,13 & 7,808 & 0,79 & 0,000 \\
Self confidence & 4,14 & 7,810 & 0,79 & 0,000 \\
Task Priority & 4,18 & 7,778 & 0,78 & 0,000 \\
Knowledge update & 4,15 & 7,852 & 0,80 & 0,000
\end{tabular}

Based on the responses of respondents, the superior indicator prioritizes subordinate tasks is the most important indicator in explaining leadership style. The result of confirmatory factor analysis shows that the knowledge update indicator is a reflection of good leadership style.

Table 3: Employee commitment

\begin{tabular}{lcccc}
\hline \multicolumn{1}{c}{ Measurements } & Mean & Critical ratio & LDF $(\lambda)$ & P-value \\
\hline Stay on the rules & 4,08 & FIX & 0.884 & 0.000 \\
Feel comfortable with work & 4,07 & 18.400 & 0.927 & 0.000 \\
Intention to leave & 3,74 & 12.750 & 0.837 & 0.000 \\
Hard work is rewarded & 4,10 & 11.859 & 0.839 & 0.000 \\
Devote all effort & 3,90 & 11.360 & 0.723 & 0.000 \\
Doing the best & 3,88 & 9748 & 0.674 & 0.000
\end{tabular}

Based on respondent's indicator to work diligently for the award is an important indicator in explaining employee commitment. The results of confirmatory factor analysis indicate that employee indicators are comfortable with the work is a reflection of the high commitment and has been shown by employees so far. 
International Journal of Arts and Humanities

ISSN: 2581-3102

Volume:02, Issue:05 "May 2018"

Table 4: Work motivation

\begin{tabular}{lcccc}
\hline \multicolumn{1}{c}{ Measurements } & Mean & Critical ratio & LDF $(\lambda)$ & P-value \\
\hline Enjoy the challenge & 4,25 & FIX & 0.351 & 0,000 \\
Progress achieved & 3,96 & 4.571 & 0.661 & 0,000 \\
Realistic goals & 4,13 & 5.644 & 0.846 & 0,000 \\
Satisfied with a difficult task & 4,16 & 4.341 & 0.690 & 0,000 \\
Enjoy the competition & 4,14 & 5.552 & 0.969 & 0,000 \\
Enjoy the responsibility & 4,29 & 4.296 & 0.398 & 0,000 \\
Coworkers affect & 3,95 & 7.468 & 0.686 & 0,000 \\
Build close relationships & 4,11 & 5.518 & 0.837 & 0,000 \\
Be part of an organization & 4,19 & 5.451 & 0.715 & 0,000 \\
Good to work together & 3,93 & 5.558 & 0.881 & 0,000
\end{tabular}

Employee desire to enjoy job responsibilities is the most important indicator in explaining work motivation. The results of confirmatory factor analysis indicate that employees always enjoy the competition in the work is a reflection of the high work motivation that has been shown employees in the work.

Table 5: Work climate

\begin{tabular}{lcccc}
\hline \multicolumn{1}{c}{ Measurements } & Mean & Critical ratio & LDF $(\lambda)$ & P-value \\
\hline Provision of cafeteria & 4,01 & FIX & 0.494 & 0,000 \\
Provision of health programs & 3,87 & 6,835 & 0.532 & 0,000 \\
Noise control & 4,11 & 8,088 & 0.808 & 0,000 \\
spacious room design & 4,00 & 19,619 & 0.489 & 0,000 \\
Good lighting & 3,86 & 6,24 & 0.534 & 0,000 \\
Air temperature control & 4,05 & 7,022 & 0.663 & 0,000 \\
Harmonization & 4,13 & 8,178 & 0.988 & 0,000 \\
Leadership can help employees & 4,14 & 8,151 & 0.987 & 0,000 \\
Security & 4,18 & 8,101 & 0.972 & 0,000 \\
Transparent working & 4,15 & 8,282 & 0.990 & 0,000
\end{tabular}


International Journal of Arts and Humanities

ISSN: 2581-3102

Volume:02, Issue:05 "May 2018"

A sense of safety in work is the most important indicator in explaining the working climate. The results of confirmatory factor analysis indicate that employees always work based on the duties and responsibilities given is a reflection of the realization of a good working climate.

Table 6: Job satisfaction

\begin{tabular}{lcccc}
\hline \multicolumn{1}{c}{ Measurements } & Mean & Critical ratio & LDF $(\lambda)$ & P-value \\
\hline $\begin{array}{l}\text { Appropriate salary } \\
\text { Allowable and satisfactory }\end{array}$ & 3,88 & FIX & 0.515 & 0,000 \\
benefits & 4,03 & 9,074 & 0.866 & 0,000 \\
satisfied with reward & 3,69 & 12,222 & 0.789 & 0,000 \\
Promotion & 4,01 & 13,343 & 0.527 & 0,000 \\
The willingness to help co- & 3,84 & 7,587 & 0.598 & 0,000 \\
workers & 4,04 & 9,117 & 0.871 & 0,000 \\
Supporting co workers & 3,85 & 13,621 & 0.747 & 0,000 \\
Leadership support & 3,65 & 9,223 & 0.977 & 0,000 \\
Good communication & 4,05 & 9,251 & 0.941 & 0,000 \\
Work according to interest & 3,66 & 9,276 & 0.978 & 0,000 \\
$\begin{array}{l}\text { Development of work } \\
\text { knowledge }\end{array}$ & & & &
\end{tabular}

The feelings of satisfied in the work shown by the fit between the jobs with the wishes of employees. The results of confirmatory factor analysis show that employees constantly improve their knowledge of employment are a reflection of employees' awareness to constantly improve their knowledge of work. 
International Journal of Arts and Humanities

ISSN: 2581-3102

Volume:02, Issue:05 "May 2018"

Table 7: Employee performance

\begin{tabular}{lcccc}
\hline \multicolumn{1}{c}{ Measurements } & Mean & Critical ratio & LDF $(\lambda)$ & P-value \\
\hline Quantity of work & 4,23 & FIX & 0.897 & 0,000 \\
Work quality & 4,09 & 18,975 & 0.619 & 0,000 \\
Work efficiency & 4,24 & 22,42 & 0.899 & 0,000 \\
Employee effort & 3,99 & 20,072 & 0.664 & 0,000 \\
Professional Employees & 4,18 & 21,444 & 0.712 & 0,000 \\
Capability & 4,00 & 19,416 & 0.638 & 0,000 \\
Working on time & 4,04 & 17,522 & 0.553 & 0,000 \\
Creativity & 4,02 & 18,087 & 0.580 & 0,000
\end{tabular}

The high level of the employee's performance can be seen by the quality of work produced by the employee during this time. The results of confirmatory factor analysis indicate that employees in work more to make the quantity of work compared with other things that trigger high levels of employee performance.

Confirmatory factor analysis (CFA)

Test results for the model based on the goodness of fit indices in Table 8 shows the criteria for a model seen meet conformance testing data.

Table 8: Goodness of Fit Overall Model

\begin{tabular}{lccc}
\hline Goodness of fit index & Cut-off Value & Results Model * & Remarks \\
\hline \multicolumn{1}{c}{$\chi^{2}-$ Chi-square } & $\begin{array}{c}\text { Expected to be } \\
\text { Small }\end{array}$ & 255,714 & Good \\
Probability & $\geq 0.05$ & 0.140 & Good \\
CMIN/DF & $\leq 2.00$ & 1.958 & Good \\
RMSEA & $\leq 0.08$ & 0.068 & Good \\
GFI & $\geq 0.90$ & 0.947 & Good \\
CFI & $\geq 0.94$ & 0.957 & Good \\
TLI & $\geq 0.94$ & 0.951 & Good
\end{tabular}

Table 8 shows that the relationship between variables in the complete model in the final stage indicates a good fit. Thus, the causal relationship between each of the tested variables can be accepted and used for subsequent purposes 
International Journal of Arts and Humanities

ISSN: 2581-3102

Volume:02, Issue:05 "May 2018"

Table 9: Hypothesis testing

\begin{tabular}{cccccccc}
\hline & Variabel & & \multirow{2}{*}{ P-value } & Direct & Indirect & Total & \multirow{2}{*}{ Remarks } \\
\hline Exogenous & Intervening & Endogenous & & & & & \\
\hline LS & - & JS & 0.018 & 0.181 & - & 0.181 & Significant \\
OC & - & JS & 0.000 & 0.226 & - & 0.226 & Significant \\
WM & - & JS & 0.000 & 0.428 & - & 0.428 & Significant \\
WCL & - & JS & 0.000 & 0.325 & - & 0.325 & Significant \\
LS & - & EP & 0.110 & 0.148 & - & 0.148 & Insignificant \\
OC & - & EP & 0.000 & 0.351 & - & 0.351 & Significant \\
WM & - & EP & 0.000 & 0.263 & - & 0.263 & Significant \\
WCL & - & EP & 0.000 & 0.243 & - & 0.243 & Significant \\
LS & JS & EP & 0,281 & 0.148 & 0.021 & 0.169 & Insignificant \\
OC & JS & EP & 0,004 & 0.351 & 0.040 & 0.394 & Significant \\
WM & JS & EP & 0,013 & 0.263 & 0.026 & 0.289 & Significant \\
WCL & JS & EP & 0,048 & 0.243 & 0.044 & 0.287 & Significant \\
- & JS & EP & 0.000 & 0.360 & - & 0.360 & Significant \\
\hline
\end{tabular}

Notes:

LS $=$ Leadership styles

OC $=$ Organizational commitment

$\mathrm{WCL}=$ Work Climate

$\mathrm{WM}=$ Work motivation

JS $\quad=$ Job satisfaction

$\mathrm{EP} \quad=$ Employee Performance

Leadership style on job satisfaction

Leadership style is a pattern of behavior that leaders have to influence, direct and guide subordinates to be able to carry out the entire mechanism of task programs really and effectively. Therefore, to improve job satisfaction and employee performance in an organization is needed an employee who has an effective leadership style so that his subordinates can work well. The first hypothesis states that leadership style variables have a positive and significant effect on job satisfaction, evidenced by the value of coefficient of 0.181 , meaning that a better leadership style will increase job satisfaction. This result shows the value is critical ratio obtained at 2.821 and the significance level $\alpha=0.018<0.05$, so the first hypothesis can be accepted or proven.

Leadership styles on job satisfaction have a positive and significant causal relationship. Positive influence of leadership style variables on job satisfaction caused by the leader always trying to do knowledge update so that subordinates can finish the job although in the implementation of the job is very difficult, but because knowledge update owned leadership then subordinates able to finish it so that subordinates feel satisfaction in work. These results confirm some of the 
International Journal of Arts and Humanities

ISSN: 2581-3102

Volume:02, Issue:05 "May 2018"

findings of previous researchers, that the transformational leadership style as measured by idealized influenced behaviors, inspirational motivation, intellectual stimulation, and individualized consideration has positive and significant impact on job satisfaction (Boamah et al., 2017). Transformational leadership style and transactional leadership style have a positive and significant effect on job satisfaction (Adler \& Reid, 2008; Golabdost \& Rezaei, 2017; Hijazi et al., 2017; Lapeña et al., 2018). Rejecting some other researchers' findings that leadership styles do not have any significant influence on job satisfaction (Yudiawan et al., 2017; Muterera et al., 2018).

Employee commitment on job satisfaction

Employee commitment is the relative strength of the individual in identifying employee involvement into the organization, including the desire to maintain membership in the organization, the readiness and willingness to strive earnestly on behalf of the organization, as well as acceptance of the values and objectives organization. The second hypothesis states that employee commitment variable has a positive and significant effect on job satisfaction. The value of the path coefficient marked positive is 0.226 , meaning that higher employee commitment will increase job satisfaction. This result shows that the value critical ratio is 4.916 and the significance level is $\alpha=0,000<0,05$, so the second hypothesis can be accepted or proven. Employee commitment on job satisfaction have a positive causal relationship and significant due to work in employees feel comfortable with the work they do so far that affect the increase in employee job satisfaction at PT Semen Tonasa. The findings of this study confirm the results of scholars' research, that employee commitment (affective, continuance and career commitment) has a positive and significant impact on job satisfaction (Carmeli \& Freund, 2003; Thamrin, 2012; Toban \& Sjahruddin, 2016).

Work motivation on job satisfaction

Motivation is a motivation or behavioral changes that arise due to the desire for the needs of an employee who is internal. The third hypothesis states that work motivation has a positive and significant effect on job satisfaction. The value of path coefficient is a 0.428 , meaning that the better work motivation will increase job satisfaction. These results indicate that the value is critical ratio obtained at 5.601 and the significance level $\alpha=0,000<0.05$, so the third hypothesis can be accepted or proven. Work motivation on job satisfaction have a positive causal relationship and significant, the condition is caused by employees in the work required to devote all the ability to produce quality work so that in the company there is a high intensity of competition but during this time employees enjoy the competition that occurred in the world of work that affects the feelings of satisfaction in employees. The results of this study confirm the findings of scholars, that the motivation of work has a significant effect on job satisfaction 
International Journal of Arts and Humanities

ISSN: 2581-3102

Volume:02, Issue:05 "May 2018"

(Hartawan et al., 2014; Ayundasari et al., 2017; Wahab et al., 2018). The refuted the findings of other scholars, that the work motivation is insignificant affect on job satisfaction (Pang \& $\mathrm{Lu}$, 2018).

\section{Work climate on job satisfaction}

Work climate is everything that exists in the work environment that is lived as a subjective influence of the formal system, the style of information from managers, and other important environmental factors on the attitudes, beliefs, values, and motivations of those who work on organization. The fourth hypothesis states that the work climate variables have a positive and significant effect on job satisfaction. The value of the path coefficient marked positive is 0.325 , meaning the better work climate will increase job satisfaction and the value is critical ratio obtained at 3,529 and the significance level $\alpha=0,000<0,05$, so the fourth hypothesis can be accepted or proven. Work climate and job satisfaction have a positive causal relationship and significant, caused by employees during this work in accordance with the duties and responsibilities imposed on him so that ultimately employees feel satisfaction in work. The results confirm the findings of scholars that the work climate has a positive and significant effect on job satisfaction (Hartawan et al., 2014; Susanti, 2016; Alim, 2016).

Leadership styles on employee performance

Leadership style is behavior and strategy, as a result of combination of philosophy, skill, nature, attitude, which is often applied by a leader when he tries to influence subordinate performance. The style of leadership represents a consistent combination of the philosophy, skills, attitudes and attitudes underlying one's behavior. The result of analysis shows that leadership style variables have an insignificant effect on employee performance because the value is critical ratio obtained only by 1.015 and the significance level $\alpha=0,110>0,05$ is required. Thus, the fifth hypothesis that the leadership style variable has a positive and significant effect on employee performance, so the fifth hypothesis is rejected or not proven.

The factors are not significant influence of leadership styles on employee performance caused by the leadership is not able to give attention to the employee personally (personal attention), that attention given by low leadership so that impact to the low ability of employees to be able to finish the workers in a timely manner. The results of this study confirm the findings of scholars, that leadership styles do not have any significant influence on the construction of job performance (Adler \& Reid, 2008; Yudiawan et al., 2017; Muterera et al., 2018). Rejecting other scholars' findings that leadership style has a significant effect on employee performance (Thamrin, 2012).

Employee commitment on employee performance 
International Journal of Arts and Humanities

ISSN: 2581-3102

Volume:02, Issue:05 "May 2018"

Commitment is a part related to a person's performance in relation to his work. If a person has a commitment to the organization, he or she will have a strong identification with the organization, have membership values, agree with the goals and the value system, will likely remain in it, and finally ready to work hard for the organization. The empirical findings resulting from this research are the direct and significant influence between employee commitment and employee performance. The sixth hypothesis states that employee commitment variable has a positive and significant effect on employee performance. This result shows that the value critical ratio is 4.943 with the coefficient value of 0.351 , meaning that the better employee commitment will improve the performance of the employees as evidenced by the significance level $\alpha=0,000$ $<0,05$, so the sixth hypothesis can be accepted or proven. Causality between these variables is significant because employees in the work to hold firm rules and regulations that apply in the organization so that between fellow employees in making good communication and appropriate goals related to the completion of work. The results of this study confirm the findings of scholars that organizational commitment was confirmed to have a significant impact on job performance (Carmeli \& Freund, 2003; Thamrin, 2012; Sjahruddin \& Sudiro, 2013; Fu \& Deshpande, 2014)

Work motivation on employee performance

Work motivation was the most vital driving force in a performance achievement. Without employee motivation will not work to complete a job maximally because there is no will that comes from within the employee itself, which emerges only a routine. Therefore, work motivation has a positive and significant contribution in improving employee performance. This means that to improve employee performance it is necessary to increase the motivation of work. The seventh hypothesis states that the variables of work motivation have a positive and significant effect on employee performance. This result shows that the value critical ratio is 3.472 with the path coefficient value of 0.263 , meaning that the better work motivation will improve employee performance and significance level $\alpha=0,000<0,05$, so the seventh hypothesis can be accepted or proven. The condition is caused because employees can build a close relationship between fellow employees and with the leadership so that efficiency in work can be achieved and then in turn create high performance. This study confirms the findings of scholars that work motivation has a significant effect on employee performance (Ayundasari et al., 2017; Prabowo et al., 2018; Pang \& Lu, 2018).

Work climate on employee performance

Work climate is a condition that influences individual expectations and perspective of the organization. The eighth hypothesis states that the work climate variables have a positive and significant effect on employee performance. This result shows that the value critical ratio is 2,832 with the coefficient value of 0,243 , it means that the better work climate will improve 
International Journal of Arts and Humanities

ISSN: 2581-3102

Volume:02, Issue:05 "May 2018"

employee performance on the level of significance $\alpha=0,000 \leq 0,05$, so that the eighth hypothesis can be accepted or proven. Evidence is caused because employees gain a sense of security in the work so that employees can spend all the ability he has in carrying out duties and responsibilities in work. The results of this study confirm the findings of scholars that a good working climate can improve employee performance (Barney, 1991, Norminah \& Fathoni, 2015; Alim, 2016; Hastari et al., 2017; Nugroho et al., 2017).

Job satisfaction on employee performance

Job satisfaction is a state of emotions a positive and pleasant person generated and assessment of a job or work experience. Job satisfaction reflects one's feelings toward one's work. The ninth hypothesis states that job satisfaction variables have a positive and significant effect on employee performance. This result shows the value is critical ratio obtained at 6.907 and the significance level $\alpha=0,000 \leq 0.05$, so the ninth hypothesis can be accepted or proven. The feeling of fasting felt by employees is due to the support that employees get from their colleagues while working or experiencing work-related problems, the condition reflects that employees have implemented professional standards in work so that by that standard they will feel satisfaction in working. This study supports the findings of scholars that job satisfaction has a significant influence on the construction of job performance (Barney, 1991, Thamrin, 2012, Alim 2016; Yudiawan et al., 2017; Ayundasari et al., 2017; Muterera et al., 2018; Pang \& Lu, 2018; Prabowo et al., 2018). The results obtained a rebuttal from other researchers, that job satisfaction had no significant impact on job performance (Fu \& Deshpande, 2014; Handayani, 2016).

The mediating effect of job satisfaction: Leadership styles on employee performance

The test results show that the value of the direct effect coefficient between leadership styles with employee performance is 0.148 and indirect effect through job satisfaction with positive value 0.021 , while the total effect is the sum of the direct effects and indirect effects through job satisfaction obtained a figure of 0.169. Thus, the impact of variables is intervening not significant, the job satisfaction have not been able to strengthen the relationship between leadership style and employee performance supported by facts and empirical data. Earlier researchers proved that job satisfaction is not the mediating variable between leadership styles and construction job performance (Yudiawan et al., 2017). Evidence is denied by other researchers that the indirect effect of transformational leadership behaviour on organizational performance, as mediated through job satisfaction, was positive and significant (Muterera et al., 2018).

The mediating effect of job satisfaction: employee commitment on employee performance 
International Journal of Arts and Humanities

ISSN: 2581-3102

Volume:02, Issue:05 "May 2018"

The test results showed that the coefficient of direct effect between employee commitments with the performance of employees is 0.351 , and the indirect effect through job satisfaction and a positive value 0,040 , while the total effect is the sum of the direct effects and indirect effects through job satisfaction obtained a figure of 0.394. This means that the impact of variables intervening can strengthen the relationship between employee commitment and employee performance supported by facts and empirical data. The results of this study are relevant to the findings of previous researchers, that Job satisfaction has a mediating role in the relationship between joint work commitment and job performance (Carmeli \& Freund, 2003).

The mediating effect of job satisfaction: work motivation on employee performance

The test results showed that the coefficient of direct effect between work motivation and performance of employees is 0.263 , and the indirect effect through job satisfaction and a positive value 0,026 , while the total effect is the sum of direct effects and indirect effects through job satisfaction obtained by the amount of 0.289 . This means that the impact of variables intervening can strengthen the relationship between work motivation and employee performance supported by facts and empirical data. The results of this study are relevant to the findings of previous researchers, which job satisfaction significantly acts as mediation in analyzing the effect of work motivation on employee performance (Ayundasari et al., 2017; Prabowo et al., 2018).

The mediating effect of job satisfaction: work climate on employee performance

The test results showed that the coefficient of direct effect between the working climates with the performance of employees is 0,243 and indirect effects through job satisfaction and a positive value 0,044 , while the total effect is the sum of direct effects and indirect effects through job satisfaction obtained by the number of 0.287 . This means that the impact of variables intervening can strengthen the relationship between work climate and employee performance supported by facts and empirical data. The results of this study are relevant to the findings of previous researchers, that there is a significant influence between the work climates on employee performance in mediation of job satisfaction (Alim, 2016).

\section{CONCLUSION}

Leadership style, employee commitment, work motivation, and work climate have a direct positive and significant influence on job satisfaction. Employee commitment, work motivation, and work climate have a positive and significant influence on employee performance, while leadership style has no significant effect on employee performance. The impact of job satisfaction as an intervening variable can strengthen the relationship between employee commitment, work motivation, and work climate on employee performance, while leadership style shows no significant relationship. 
International Journal of Arts and Humanities

ISSN: 2581-3102

Volume:02, Issue:05 "May 2018"

Job satisfaction has a positive and significant effect on employee performance. The study recommends that leadership styles still need to be improved by maximizing the attention of the boss personally, the boss always consulted with subordinates, likes the detailed procedures, and the boss always treats the subordinates alike so as to support the increase in employee job satisfaction in the future. Employee commitment needs to be improved by doing the best because the happiness of life is in the company, and exerting all the effort beyond the expected in the work, thus supporting the increase in employee job satisfaction in the future. Work motivation still needs to be empowered by enjoying difficult challenges and enjoying responsibilities in order to improve employee work satisfaction in the future. Working climate still needs to be improved by providing enough space, companies provide canteen, companies provide health programs; and lighting in the workplace in order to increase employee work satisfaction in the future.

\section{REFERENCES}

[1] Adler, RW, \& Reid, J. (2008). The effects of leadership styles and budget participation on job satisfaction and job performance. Asia-Pacific Management Accounting Journal, 3 (1).

[2] Alim, DF (2016). The Influence of Organizational Climate And Job Stress On The Performance Of Nurse Through Job Satisfaction As Intervening Variable At Islamic Hospital Jemursari (Doctoral dissertation, Airlangga University).

[3] Ayundasari, DY, Sudiro, A., \& Irawanto, DW (2017). Improving employee performance through work motivation and self-efficacy mediated by job satisfaction. journal application management, 15 (4), 587-599.

[4] Barney, J. (1991). Firm resources and sustained competitive advantage. Journal of management, 17 (1), 99-120.

[5] Bass, BM (1990). From transactional to transformational leadership: Learning to share the vision. Organizational dynamics, 18 (3), 19-31.

[6] Boamah, SA, Laschinger, HKS, Wong, C., \& Clarke, S. (2017). Effect of transformational leadership on job satisfaction and patient safety outcomes. Nursing outlook. https://doi.org/10.1016/j.outlook.2017.10.004

[7] Burns, JM (1978). Leadership. New York Harper and Row.

[8] Carmeli, A., \& Freund, A. (2003). Work commitment, job satisfaction, and job performance: An empirical investigation. International Journal of Organization Theory \& Behavior, 7 (3), 289-309.

[9] Daft, Richard L. (2006). Management, 6th Edition. Jakarta: Salemba empat.

[10] Davis K, Newstrom JW. (2001). Organizational Behavior. Volume 1. Translation. Jakarta: Erlangga Publisher. 
International Journal of Arts and Humanities

ISSN: 2581-3102

Volume:02, Issue:05 "May 2018"

[11]Duncan, RB (1972). Characteristics of organizational environments and perceived environmental uncertainty. Administrative science quarterly, 313-327.

[12] Fu, W., \& Deshpande, SP (2014). The impact of caring climate, job satisfaction, and organizational commitment on job performance of employees in a China's insurance company. Journal of Business Ethics, 124 (2), 339-349.

[13] Gibson, James L., John M. Ivancevich and James H. Donnelly, Jr. (1994). Organization and Management. Behavior, Structure, Process. Fourth edition. Jakarta: Erlangga

[14]Golabdost, A., \& Rezaei, M. (2017). Interventional Role of Job Satisfaction in the Effectiveness of Leadership Styles on Organizational Commitment. Mediterranean Journal of Social Sciences, 7 (5 S1), 186.

[15] Greenberg, J. \& Robert A. Baron. (2003). Behavior in Organization International Edition, New Jersey: Prentice Hall

[16] Handayani, R. (2016). Influence of performance measurement system, reward system, organizational culture, psychological empowerment and job satisfaction to managerial performance (Empirical Study At PT Bank Rakyat Indonesia Tbk Branch Jambi). Journal of Accounting \& Finance of Unja, 1 (4).

[17] Handoko T. Hani (2002), Management; Second Edition, Thirteenth Print. Yogyakarta: BPFE

[18] Hartawan, IK, Dantes, N., \& Yudana, IM (2014). Determination of Principal Managerial Ability, Working Climate And Teacher Work Motivation Of Teacher Work Satisfaction Of SMP Negeri 3 Bangli. Journal of Indonesian Education Administration, 5 (1).

[19] Hastari, S., Djaziah, N., Wahyudi, P., \& Pudyaningsih, AR (2017). Contribution of leadership function of work motivation and work climate to lecturer performance. Journal Ema (Economics of Management Accounting), 1 (1).

[20]Hijazi, S., Kasim, AL, \& Daud, Y. (2017). Leadership Styles and Their Relationship with the Private University Employees' Job Satisfaction in United Arab Emirates. Journal of Public Administration and Governance, 6 (4), 110-124. http://dx.doi.org/10.5296/jpag.v6i4.10347

[21] Koontz, Harold, \& Cyrill O 'Donnell. (1972). Principle Of Management, Analysis Of Managerial Function, 5th edition. Tokyo: Mc Graw-Hill, Kogakusha Ltd

[22] Lapeña, LFR, Tuppal, CP, Loo, BGK, \& Abe, KHC (2018). Transformational and Transactional Leadership Styles of Nurse Managers and Job Satisfaction among Filipino Nurses: A Pilot Study. Nurse Media Journal of Nursing, 7 (2), 65-78. https://doi.org/10.14710/nmjn.v7i2.15171

[23]Lee, K., Allen, NJ, Meyer, JP, \& Rhee, KY (2001). The Three-Component Model of Organizational Commitment: An Application to South Korea. Applied Psychology, 50 (4), 596-614. 
International Journal of Arts and Humanities

ISSN: 2581-3102

Volume:02, Issue:05 "May 2018"

[24] Mahsun, Mohamad. (2006). Public Sector Performance Measurement. Publisher BPFE, Yogyakarta.

[25] Mangkunegara, AA Anwar Prabu. (2006). Planning and Development. Human Resource Management. Bandung: PT. Refika Aditama

[26] Moekijat, (2002). Archives Management. Bandung: Rineka Cipta

[27]Muterera, J., Hemsworth, D., Baregheh, A., \& Garcia-Rivera, BR (2018). The leaderfollower dyad: The link between leader and follower perceptions of transformational leadership and its impact on job satisfaction and organizational performance. International $\begin{array}{lllll}\text { Public } & \text { Management } & \text { Journal, } & 21 & \text { (1), }\end{array}$ http://dx.doi.org/10.1080/10967494.2015.1106993

[28] Norminah Indah, M., \& Fathoni, MA (2015). Effect of Environment, Communication and Leadership on The Employee Performance of the Office of Cipta Karya and Spatial Planning of Housing of Central Java Province. Journal of Management, 1 (1).

[29] Nugroho, R., Sunuharjo, BS, \& Ruhana, I. (2017). The Influence of BPS Organization Climate And Job Stress On Employee Performance (Study On Employees Central Bureau of Statistics (BPS) Kediri). Journal of Business Administration, 45 (1), 19-26.

[30]Pang, K., \& Lu, CS (2018). Organizational motivation, employee job satisfaction and organizational performance: An empirical study of container shipping companies in Taiwan. Maritime Business Review. https://doi.org/10.1108/MABR-03-2018-0007

[31] Prabowo, TS, Noermijati, N., \& Irawanto, DW (2018). The Influence Of Transformational Leadership And Work Motivation On Employee Performance Mediated By Job Satisfaction. Journal of Application Management, 16 (1), 171-178.

[32] Rivai, V. (2008). Human Resource Management For Companies: from Theory and Practice. PT. Raja Grafindo Persada. Jakarta.

[33]Robbins, Stephen P. \& Judge, Timothy A. (2007). Organizational Behavior, ${ }^{2 n d}$ book. Jakarta: Salemba Empat.

[34] Robbins, Stephen P. (2006). Complete Organizational Behavior Tenth Edition, Benjamin Molan Language Translation, Gramedia Group Index, Jakarta

[35] Simamora, Henry. (2004). Human Resource Management, Third Edition ,. Yogyakarta, STIE YPKN

[36] Sjahruddin, H., \& Sudiro, AA (2013). Organizational justice, organizational commitment and trust in manager as predictor of organizational citizenship behavior. Interdiciplinary J. of contemporary Res. Bus (IJCRB), 4 (12), 133-141.

[37] Steers, Richard M. \& Lyman W. Porter. (2005). Organizational effectiveness, Magdalene's translation Janin, Jakarta: Erlangga

[38] Susanti, D. (2016). Contribution of work climate and incentive to job satisfaction of private smk teachers in Bukittinggi. Patches, 11 (1), 11-25. 
International Journal of Arts and Humanities

ISSN: 2581-3102

Volume:02, Issue:05 "May 2018"

[39] Tagiuri, R., Litwin, GH, \& Barnes, LB (1968). Organizational climate: Explorations of a concept. Division of Research, Graduate School of Business Administration, Harvard University.

[40] Thamrin, HM (2012). The Influence of Transformational Leadership and Organizational Commitment on Job Satisfaction and Employee Performance. International Journal of Innovation, Management and Technology, 3 (5), 566.

[41]Toban, C., \& Sjahruddin, H. (2016). The Antecedent and Consequence of Organizational Commitment and Job Satisfaction. Journal of Business and Management Sciences, 4 (2), 2633. https://doi.org/10.12691/jbms-4-2-1

[42] Wahab, E., Shamsuddin, A., \& Abdullah, NH (2018). Exploring Relationship Between Perceived Motivation Factors and Job Satisfaction. Advanced Science Letters, 24 (6), 46094611. https://doi.org/10.1166/asl.2018.11665

[43] Wirawan. (2007). Culture and Organizational Climate: Theory of Applications and Research. Jakarta: Salemba Empat.

[44] Wright, PM, Gardner, TM, \& Moynihan, LM (2003). The impact of HR practices on the performance of business units. Human resource management journal, 13 (3), 21-36.

[45] Yudiawan, M., Setiawan, M., Irawanto, DW, \& Rofiq, A. (2017). The influences of leadership styles, organizational communication, and job satisfaction toward employees' job performance in doing construction jobs: a study on three construction companies in jakarta. Russian Journal of Agricultural and Socio-Economic Sciences, 65 (5), 168-180. https://doi.org/10.18551/rjoas.2017-05.23

[46] Yukl, G., \& Lepsinger, R. (2005). Why integrating the leading and managing roles is essential for organizational effectiveness. Organizational Dynamics, 34 (4), 361-375. 